\title{
A RELIGIÃO CIVIL E O LEGISLADOR NO MODELO CONTRATUALISTA DE ROUSSEAU*
}

\author{
Thomaz Kawauche** *** \\ http://orcid.org/0000-0002-7275-6814 \\ kawauche@gmail.com
}

RESUMO No "Contrato social", os capitulos do legislador e da religião civil parecem incompativeis com a ideia de um corpo político laico que se autoinstitui enquanto tal e que só se submete a leis estabelecidas por seus próprios membros. Trata-se de examinar neste artigo o método de exposição adotado por Rousseau para descrever, à luz da tradição, sua doutrina contratualista e, em particular, esclarecer nessa doutrina a necessidade da relação entre política e religião no problema da origem da sociedade.

Palavras-chave Legislador; Contrato Social; Religião Civil; Direito Político; História.

ABSTRACT The chapters "Legislator" and "Civil Religion" in the Social Contract do not seem to conciliate with the idea of a self-instituted political body that is solely submitted to laws established by its own members. This article aims at examining the exposition method adopted by Rousseau to describe - tradition considered - his contractual doctrine and, in particular, at elucidating, in this doctrine, the necessity of a relation between Politics and Religion in the issue of Society's origin.

Keywords Legislator; Social Contract; Civil Religion; Political Right; History.

* Artigo submetido em 09/07/2018 e aprovado em 13/11/2018.

** Universidade Federal de São Carlos. São Carlos, SP, Brasil.

*** Doutor em Filosofia pela Universidade de São Paulo. Bolsista CAPES-PNPD vinculado ao Programa de PósGraduação em Filosofia da Universidade Federal de São Carlos. 
Os capítulos do legislador e da religião civil no "Contrato social" (1762) parecem se harmonizar pouco com o princípio da autonomia que, como se sabe, norteia a obra. Um personagem excepcional, acima dos homens e exterior ao corpo político, que guia o soberano na instauração do sistema legislativo, assim como uma profissão de fé intimamente ligada à legislação e sem a qual a unidade do Estado ficaria ameaçada, parecem exigências doutrinárias incompatíveis com a ideia de uma associação laica que se autoinstitui enquanto tal e que só se submete às leis estabelecidas por seus próprios membros. A questão é: como pode um povo livre sujeitar-se a leis instituídas pelos deuses? Poderíamos, é verdade, interpretar o corpo político do "Contrato" à luz do paradigma newtoniano e enxergar no legislador a causa final que extrapola o campo dos fenômenos observáveis: neste caso, os esquemas de inteligibilidade das ciências mecanicistas justificariam a circunscrição da teoria política do genebrino ao domínio da experiência. Contudo, mesmo que excluíssemos a dimensão metafísica na "ciência da legislação" almejada por Rousseau e aceitássemos o legislador como uma categoria operatória do pensamento, continuaríamos com a dificuldade de compreender a premissa finalista dos sentimentos religiosos como móbiles práticos para a efetivação dos laços sociais.

Ora, se a sacralidade da ordem social está, como afirma Rousseau, nas convenções e não na natureza, ${ }^{1}$ é preciso esclarecer o porquê do extraordinário recurso aos sentimentos religiosos, seja naquilo que diz respeito ao caráter divino da autoridade do legislador, seja no concernente à obrigação imposta aos cidadãos pelos dogmas da "profissão de fé puramente civil". Embora Rousseau não defenda a submissão da política à teologia, é inegável que, à primeira vista, seus esforços para afirmar a autonomia do corpo político parecem inócuos diante de uma "figura paternalista"" que, com o intuito de assegurar a preservação do Estado, demanda de todos os cidadãos a crença na providência, na alma imaterial e no tribunal de justiça do além-túmulo, ao mesmo tempo que os persuade, como um profeta, falando pela "boca dos imortais" a fim de que os fiéis súditos conformem seus interesses à vontade geral. Isso, porém, somente à primeira vista. Este artigo pretende apresentar uma leitura do "Contrato" mostrando a necessidade do legislador e da religião civil, entendidos como instrumentos de moralidade mais eficazes do que a

1 "Mas a ordem social é um direito sagrado, que serve de base a todos os outros. No entanto, esse direito não vem da natureza; é fundado, pois, em convenções" (Rousseau, 1964, p. 352).

2 A expressão é de Luiz Roberto Salinas Fortes (1976, p. 97), que chegou a se referir ao legislador como a "vanguarda política" (ibid., p. 103). 
coerção legalista do governo, quer no âmbito do problema da obediência às leis civis segundo a antropologia de Rousseau, quer do ponto de vista da coerência que organiza a economia interna do escrito em questão.

Ao longo dos quatro livros do "Contrato social", Rousseau discute as condições de possibilidade de uma associação política, levando em conta não apenas os princípios necessários à constituição do Estado ideal, mas também certos problemas reais das sociedades existentes. "Quero indagar se pode existir, na ordem civil, alguma regra de administração legítima e segura [...]" (Rousseau, 1964, p. 351). A exigência é dupla: legitimidade e segurança. Como explica Victor Goldschmidt (1984, p. 145), há na arquitetônica do "Contrato" uma "bipartição fundamental" entre a essência e a existência de seu objeto; Rousseau opõe, de um lado, o ponto de vista do direito, que diz respeito à origem da ordem jurídica na qual justiça e interesse estariam em perfeito equilíbrio, e, de outro, o ponto de vista dos fatos, não como mera compilação erudita para a memória, mas à maneira do "Espírito das leis", isto é, buscando-se as "relações necessárias" em meio à "infinita diversidade de leis e costumes" nas histórias dos povos policiados (Montesquieu, 1996, pp. 5 e 11). Tal estudo, cujo objeto é a complexa relação entre teoria e prática, procura aplicar o método experimental ao estudo científico do direito a fim de julgar os fatos empíricos à luz de princípios de justiça, coisa que o próprio Rousseau já havia ensaiado de modo sistemático no "Discurso sobre a origem da desigualdade entre os homens" (1755): "examinar os fatos [...] pelo direito" (Rousseau, 1964, p. 182). No âmbito dos saberes da época, trata-se de um procedimento que se inscreve na tradição jusnaturalista e atinge um alto nível de formalismo no "Contrato social", onde será efetivamente operado como regra geral para direção do pensamento. Goyard-Fabre (2006, pp. 59-79) explica que é a interrogação reflexiva e normativista do "Contrato" que inspirará Kant a realizar sua "guinada crítica da razão reflexionante". Dados os limites deste artigo, não trataremos da história das doutrinas do pacto civil, e a análise aqui apresentada se restringirá ao modelo contratualista de Rousseau.

Podemos dizer que, no "Contrato", o escritor genebrino considera um mesmo problema-o corpo político possível-apoiando-se em duas perspectivas, uma abstrata e outra factual. No transcurso do tempo lógico da exposição, Rousseau alterna sistematicamente entre esses dois pontos de vista, os quais, na medida em que se complementam, ampliam o conhecimento que se tem do objeto investigado. Essa técnica, que poderíamos entender como um método descritivo, resulta num alargamento do campo visual do leitor, o que permite a Rousseau colocar, lado a lado, argumentos filosóficos acerca dos princípios do direito político e relatos de fatos das sociedades historicamente constituídas, 
sem que isso implique incoerência do discurso. ${ }^{3}$ Embora Rousseau se detenha, ora na ordem legítima desejada, ora na constituição real das sociedades, seria incorreto falar em contradição, pois esses dois modos de se apreciar o corpo político não rivalizam entre si, mas se integram numa mesma imagem. Concluise daí que, no "Contrato", a relação entre o direito político, concernente ao plano teórico do dever-ser, e a realidade histórica, concernente às coisas situadas no quadro de suas causas efetivas, não é de subordinação nem de exclusão recíproca, mas de soma; na exposição da doutrina de Rousseau, o ideal e o real se adicionam.

O primeiro parágrafo do livro I do "Contrato" não deixa dúvidas: temos aí um enunciado de método na pesquisa de Rousseau (1964, p. 351). O autor anuncia que, em seu exame, irá considerar os homens "como são" (ou seja, segundo a realidade concreta) e as leis "como podem ser" (isto é, concebidas com vistas à conservação do corpo político) de maneira a "aliar sempre nessa busca o que o direito permite e o que o interesse prescreve, a fim de que $a$ justiça e a utilidade jamais se encontrem separadas" (meus os itálicos). Ao aproximar duas representações da sociedade segundo os saberes do direito político e da história, tudo se passa como se Rousseau anunciasse a montagem de um enquadramento maior de seu problema e, para expressar tal visada expandida, recorresse a um discurso composto por dois registros operados simultaneamente. Eis aí uma possível interpretação da passagem no livro V do "Emílio" em que Rousseau distingue o estudo abstrato dos "princípios do direito político" (seu projeto no "Contrato") do estudo do "direito positivo dos governos estabelecidos" (do "Espírito das leis" de Montesquieu), este relativo ao plano concreto do Estado e das leis tais como são. Embora sejam diferentes, tanto uma investigação quanto a outra se relacionam necessariamente enquanto ciências solidárias: "quem quer julgar de modo sadio os governos tais como existem é obrigado a reunir os dois estudos; é preciso saber o que deve ser para bem julgar o que é" (Rousseau, 1969, pp. 836-837).

Interessa-nos perceber que os contrapontos entre o real e o abstrato se repetem de modo regular nos capítulos da lei e do legislador no "Contrato". Ao acompanharmos o fio do argumento, vemos Rousseau alternar entre os princípios e os fatos, seja contrastando uma instância superior (da justiça dos deuses) a uma outra inferior (do governo dos homens), seja comparando as descrições das qualidades esperadas de um legislador perfeito aos exemplos

3 A frase célebre que abre o primeiro capítulo do "Contrato social" é uma amostra significativa do que se verifica ao longo de todo o tratado: "O homem nasceu livre [ponto de vista do direito] e por toda parte ele está agrilhoado [ponto de vista dos fatos]" (Rousseau, 1964, p. 351). 
históricos de obras de grandes legisladores, como Moisés ou Numa. Assim como se verifica no plano geral do tratado, também nos capítulos aqui enfocados Rousseau nos mostra duas vias complementares de apreciação de seu objeto: uma perspectiva hipotética, voltada para os fundamentos do direito político, e outra, que poderíamos chamar de empirista, focada no direito real tal qual produzido nas situações concretas do mundo humano. Ora, o sistema de diferenças engendrado dessa comparação é a base de uma crítica social poderosa, tanto no prisma do indivíduo quanto no da coletividade, como vemos no "Discurso sobre a desigualdade"; porém, no "Contrato", Rousseau explora outra faceta desse esquema discursivo ao buscar refletir acerca das condições de possibilidade de uma sociedade justa na perspectiva simultânea dos domínios da teoria e da prática. Convém notar que tal divisão remonta ao rascunho do "Contrato", texto conhecido como "Manuscrito de Genebra", quando Rousseau distingue figuradamente, em referência ao Estado, "o mecânico que inventa a máquina" e "o trabalhador que a constrói e que a faz funcionar" (Rousseau, 1964, pp. 313 e 381), sem contudo dissociar o conceito de sua aplicação, uma vez que é em relação à mesma máquina que, do ponto de vista normativo (pois a metáfora se repete no "Contrato"), são definidas tanto a figura do inventor quanto a do operador.

Uma visada panorâmica da obra nos ajuda a esclarecer esse ponto. A questão que conduz a investigação de Rousseau no "Contrato" é: qual a regra legítima e segura para administrar a sociedade? A resposta, como todos sabem, é a vontade geral. Porém, para que a vontade geral se expresse efetivamente na matéria das leis, ou ainda, para que ela seja, de fato e de direito, a regra de ordenamento do estado civil, é preciso que o povo nascente torne-se consciente da necessidade de um sistema legislativo. A arte do legislador consiste justamente em despertar no povo essa consciência, sem a qual não haveria solidez nos laços estabelecidos mediante o pacto civil: "cada indivíduo, não experimentando outro plano de governo afora aquele que se refere ao seu interesse particular, tem dificuldade em perceber as vantagens que deve tirar das privações contínuas impostas pelas boas leis" (Rousseau, 1964, p. 383). Ora, a linguagem da religião é precisamente a chave do enigma; é por intermédio do discurso dos deuses que o legislador consegue ensinar o povo a traduzir, por conta própria, o princípio da vontade geral em resoluções de justiça, não à maneira dos tribunais de casuística, mas em termos de raciocínios ordenados sob o crivo de regras gerais previamente estabelecidas. Essa solução, evidentemente, comporta riscos, mas Rousseau os conhecia muito bem: basta lermos no capítulo da religião civil (ibid., pp. 465-467) a crítica à "pátria do cristão", que se preocupa mais com "as coisas do céu" do que com o corpo político. Contudo, devemos observar que, 
embora seja uma proposta polêmica, ela não deixa de atender aos critérios de legitimidade e segurança que parametrizam a discussão em torno do legislador. Vejamos por quê.

Em primeiro lugar, o dado empírico: o povo não sabe raciocinar e, graças aos hábitos engendrados pelas opiniões vulgares, teme mais a vontade divina do que a vontade do soberano. É do ponto de vista dos fatos que Rousseau se refere à "multidão cega que nunca sabe o que quer porque raramente sabe o que lhe é bom" (Rousseau, 1964, p. 380). Todavia, é preciso lembrar que, com essas palavras, Rousseau não está afirmando que a ignorância do povo é insuperável, pois isso seria incompatível com sua doutrina da consciência moral; ${ }^{4}$ a cegueira cognitiva da multidão deve, portanto, ser entendida como aquisição cultural, ou seja, efeito da má educação resultante dos progressos funestos da vida coletiva, de acordo com a genealogia das relações humanas apresentada no "Discurso sobre a origem da desigualdade". De todo modo, Rousseau não se limita a diagnosticar a doença: ele também prescreve um remédio. Diante da ignorância do vulgo, a "inteligência superior" daquele que guia o corpo político em direção às luzes públicas revela-se na estratégia de valer-se dos sentimentos religiosos para produzir "sentimentos de sociabilidade": uma vez que os homens comuns acham mais importante honrar os deuses do que seguir as máximas da política, a "razão sublime" do legislador "põe as decisões na boca dos imortais, para arrastar pela autoridade divina aqueles que a prudência humana não poderia abalar" (Rousseau, 1964, p. 384). Sem empregar "nem

$4 \mathrm{Na}$ antropologia do "Emílio", é pressuposto que "o sentimento do justo e do injusto é inato no coração do homem" (Rousseau, 1969, p. 286, nota). Há uma inclinação natural para a estima do bem que Rousseau, na doutrina da consciência moral exposta na "Profissão de fé do vigário saboiano", descreve com as seguintes palavras: "Existe, pois, no fundo das almas um princípio inato de justiça e de virtude com base no qual, apesar de nossas próprias máximas, julgamos nossas ações e as de outrem como boas ou más, e é a esse princípio que dou o nome de consciência" (ibid., p. 598). Para a correta interpretação do texto, importa notar que a representação do homem no "Contrato" é a que Rousseau apresenta no "Emílio," e não a do "Discurso sobre a origem da desigualdade": embora haja no "Emílio" diversas referências ao estado de natureza do "Discurso", é com base num modelo antropológico que não pode ser reduzido à constituição quase animal do homem no estado de natureza anterior à sociabilidade que Rousseau desenvolve suas análises sobre a entrada do adolescente no mundo dos homens (livros IV e V). Tanto isso é verdade, que Rousseau declara no "Emílio": "como não podemos duvidar, o homem é sociável por natureza" (ibid., p. 600). Na presente análise, limitamo-nos a observar que, no capítulo da religião civil do "Contrato", é o modelo do homem naturalmente inclinado para a vida civil que Rousseau tem em vista quando investiga a relação entre os móbiles da ação e a sociabilidade humana; não por acaso, os artigos de fé da religião civil são considerados, "não precisamente como dogmas religiosos, mas como sentimentos de sociabilidade" (Rousseau, 1964, p. 468, meus itálicos). O que Rousseau afirma acerca da religião civil diz respeito mais aos efeitos sociais das religiões em geral do que ao conteúdo dogmático dos credos das igrejas históricas: ele está menos interessado nos fins últimos vislumbrados por Deus do que na inclinação para a sociabilidade que se verifica no modo de conduta do súdito fiel sempre que este cumpre de bom grado a "profissão de fé puramente civil". Se for preciso falar em finalidade na doutrina contratualista de Rousseau, convém enfatizar que não se trata das causas finais como na metafísica do século XVII, mas de fins próximos que, como numa etiologia hipocrática aplicada à saúde do corpo moral, dizem respeito meramente à manutenção da máquina política. 
a força nem o raciocínio", recorre "a uma autoridade de outra ordem, capaz de conduzir sem violência e persuadir sem convencer" (Rousseau, 1964, p. 383). Evidentemente, o legislador poderia abusar de sua autoridade a fim de usurpar a soberania do povo e, como charlatão que "finge um comércio secreto com alguma divindade" (ibid., p. 384), reivindicar para si mesmo o título de lugar-tenente de Deus na terra; mas, em vez disso, conduz-se como um agente moral kantiano (cujo móbil é o respeito à lei, e não o interesse particular) e mostra-se fiel à fórmula de prudência da separação dos poderes: "aquele que manda nas leis não deve tampouco mandar nos homens" (ibid., p. 382). O "verdadeiro milagre" ao qual se refere Rousseau é que, por princípio, o legislador do "Contrato" não se vale do lugar privilegiado que ocupa entre os homens para dominá-los: embora sua empresa seja "acima da força humana", sua autoridade, em contrapartida, "nada é", e, quanto à religião, limita-se a apresentar aos homens um novo código moral, tão útil e tão sagrado quanto os mandamentos divinos, a saber, o sistema de leis instituído pelo soberano. Sem se aproveitar de sua influência moral para criar uma nova igreja da qual ele mesmo seria o pontífice, o legislador contenta-se em chamar a atenção de seus ouvintes para o caráter sagrado tanto das leis existentes quanto do contrato originário. Dito de outro modo, ele faz bom uso das crenças de seu auditório para sensibilizá-lo quanto à necessidade prática da obediência à lei em geral, isto é, não apenas aos mandamentos que expressam a vontade divina, mas também - e sobretudo - às normas cívicas que declaram a vontade geral do corpo político: os povos devem estar "submetidos às leis do Estado como às da natureza" (ibid., p. 383). O movimento é análogo ao da passagem da religião natural do "Emílio" para a religião civil do "Contrato" que analiso em outro lugar (Kawauche, 2013, capítulos 2 e 3).

O desafio teórico em questão poderia ser assim enunciado: como fazer o povo compreender a necessidade da instituição das leis justas se somente as leis instituídas pelo povo podem despertar neste a consciência de justiça? Rousseau formula o problema da obediência às leis nos termos da questão paradoxal colocada por Montesquieu (1951, p. 70) nas "Considerações sobre as causas da grandeza dos romanos e de sua queda" (1734), cuja referência é explícita no texto do "Contrato": "No nascimento das sociedades, são os chefes das repúblicas que fazem a instituição, e em seguida é a instituição que forma os chefes das repúblicas". Posto nesses termos, há no espírito do problema um comércio necessário e impossível que se estabelece entre o mundo real dos homens movidos por interesses e o mundo imaginário das instituições pautadas pelo bem comum; comércio este em que as trocas se realizam de acordo com o princípio da utilidade, ao mesmo tempo que são confrontadas pela ideia 
de utilidade pública concebida no horizonte heurístico onde se vislumbra a confluência dos interesses. É nesse contraste de registros - do particular e do coletivo - que Rousseau busca extrair do próprio veneno seu antídoto ao examinar os efeitos benéficos da religião na prática da política. Trata-se, como se sabe, de um viés pragmático recuperado de Maquiavel acerca da relação entre religião e política nos "Discorsi": 5 "na origem das nações, uma serve de instrumento à outra" (Rousseau, 1964, p. 384). Evidentemente, não faltariam exemplos funestos para demonstrar os abusos históricos ocorridos em nome da fé, mas, fiel ao seu próprio método, Rousseau interessa-se em primeiro lugar pela perspectiva do direito: "deixando de lado as considerações políticas, voltemos ao direito e fixemos os principios relativos a esse ponto importante" (ibid., p. 467, itálicos meus).

Com efeito, importa notar a distinção metodológica de se julgar os fatos pelo direito, e não o inverso: se o recurso aos sentimentos religiosos leva a abusos, é preciso explicitar o seu uso regulado com vistas a efeitos salutares, o que condicionaria a possibilidade de uma administração terapêutica (poderíamos dizer até mesmo farmacológica) dos mesmos móbiles que, em sociedades corrompidas, engendram apenas comportamentos viciosos. Vislumbrada à luz da justa medida dos pharmakoi da escola de Cós, a relação utilitária entre religião e política funciona, segundo Rousseau, como via prática de conciliação para unir justiça e interesse, evitando-se assim jogar a água da banheira junto com o bebê, ao mesmo tempo que se preserva, do ponto de vista do direito, a integridade dos fundamentos da ordem civil ideal. Ao falar da religião civil, Rousseau coloca-nos, portanto, no registro da história, muito embora a própria religião civil seja a-histórica. ${ }^{6} \mathrm{Na}$ verdade, a religião civil aponta para o registro do direito puro (i.e., incondicionado), pois é justamente o discurso normativo da conduta que deve servir de parâmetro para se julgar os fatos da história sem o risco de obnubilamento dos princípios em meio ao devir circunstancial da situação concreta. $\mathrm{O}$ procedimento do legislador consiste basicamente em

5 "E quem considerar bem as histórias romanas, verá como a religião servia para comandar os exércitos e infundir ânimo na plebe, para manter os homens bons e fazer com que os reis se envergonhem. [...] E, de fato, nunca houve ordenador de leis extraordinárias, em povo nenhum, que não recorresse a Deus; porque de outra maneira elas não seriam aceitas: pois há muitas boas coisas que os homens prudentes conhecem, mas que não têm em si razões evidentes para poderem convencer os outros. Por isso, os homens sábios, que querem desembaraçar-se dessa dificuldade, recorrem a Deus. Foi o que fizeram Licurgo, Sólon e muitos outros que tinham as mesmas finalidades. [...] E, assim como a observância do culto divino é razão da grandeza das repúblicas, também o seu desprezo é razão de sua ruína. Pois onde falta o temor a Deus, é preciso que o reino arruíne-se ou que seja mantido pelo temor a um príncipe que supra a falta de religião. E como os príncipes têm vida curta, o reino só poderá desaparecer logo, ao desaparecer a virtù dele. [...]" (Maquiavel, 2007, pp. 50-51).

6 Esse ponto é desenvolvido em Kawauche (2013, cap. 3). 
deslocar a lei, originalmente concebida na instância superior das "sãs máximas da política" (Rousseau, 1964, p. 383), para a situação rasteira da verdade efetiva dos homens, num movimento que pode ser metaforicamente compreendido como uma tradução das leis do céu para a "língua do povo". ${ }^{7}$ É aí, nessa manifestação demiúrgica do mundo das ideias do direito no mundo sensível da história - "revelação do humano", diria Starobinski (1971, pp. 339-340) - que o registro do discurso religioso aparece sobreposto ao do dever-ser; e não sem razão, pois só um discurso dessa natureza é compreensível por parte de homens supersticiosos que, dada a falta de desenvolvimento das relações sociais que esclarecem o juízo, ainda não sabem raciocinar, e que, por isso mesmo, só cumprem a lei porque temem possíveis castigos vindos de seu autor.

Não seria absurdo, neste ponto, comparar o povo cego do "Contrato" à criança a ser educada do "Emílio". Afinal, trata-se, em ambos os casos, da estratégia pedagógica de tornar acessível um conhecimento abstrato a uma razão que ainda não sabe lidar com objetos puramente intelectuais, como se o povo do contrato fosse uma criança incapaz de falar na língua dos bens futuros: "Refletindo no que lhe pode ser útil em outra idade, não lhe faleis senão daquilo cuja utilidade ela observe no presente" (Rousseau, 1969, p. 453). A religião é útil, tanto no "Emílio" quanto no "Contrato", para que a razão realize, nos indivíduos, seu movimento progressivo de saída da minoridade rumo ao ideal da autonomia mediante uma presentificação do porvir, quer para dar coerência à visão mecanicista (antifinalista e a-histórica, portanto) do corpo político relativamente aos móbiles passionais, quer para se pensar de modo realista numa ideia de justiça considerando-se os interesses de homens "tais como são", os quais não buscam nada além da satisfação das carências imediatas. Essa passagem da obediência por medo para a obediência por interesse generaliza o móbil das ações em relação ao modelo hobbesiano, ${ }^{8}$ e seu sucesso depende, basicamente, da boa retórica do legislador, que, como diz Rousseau, deve ser capaz de "relacionar aos seus olhos [do povo] os lugares e os tempos" (Rousseau, 1964, p. 380).

Por sua eloquência, o legislador é, segundo Jean Starobinski (1982, p. 196), aquele que "detém a arte consumada da linguagem", pois consegue

7 "Os sábios que querem falar com sua língua para o vulgo não poderão ser entendidos. Ora, há mil tipos de ideias impossíveis de serem traduzidas na língua do povo" (Rousseau, 1964, p. 383, meu o itálico).

8 Lemos no "Discurso sobre a origem da desigualdade": "o amor do bem-estar é o único móbil das ações humanas" (cf. Rousseau, 1964, p. 166). Conclui-se daí que a paixão do medo nada mais seria do que um caso particular de motor das ações humanas. É, portanto, com base na ideia de interesse, entendido como amor-próprio em sentido amplo, que Rousseau elabora uma teoria contratualista mais abstrata do que as de Hobbes e Locke. Sobre a centralidade do interesse na filosofia política de Rousseau, cf. Bernardi (2006, cap. 6). 
criar um passado mítico em torno da fundação da ordem presente que será constantemente rememorado pelo povo. A unidade social depende em certo sentido de uma história que possa ser reconhecida como legítima, e isso é por excelência a tarefa sagrada confiada aos legisladores. Como explica Jean-Louis Quantin (1989, p. 156), a imagem recorrente do legislador na literatura do século XVIII se inscreve nas estruturas fundamentais da "épistémè da idade clássica", por meio das quais os homens pensam a ordem civil e a própria vida. Todavia, mais do que isso, o legislador de Rousseau é aquele que inscreve o corpo político no registro discursivo da sincronia sem eliminar, como no "Leviatã" de Hobbes, o registro da diacronia, já que há uma dupla camada (evitemos falar em dialética!) na exposição da doutrina. De fato, como observa Quantin, a imagem do legislador no século XVIII dizia respeito à passagem da barbárie para a civilização, e funcionava como um "operador linguístico" que "estabelece um sistema de signos", permitindo ao povo instituído "tornar-se objeto de discurso porque está ordenado" (ibid.). Ou seja, o legislador no século XVIII é uma figura de linguagem capaz de fundir as descrições lógico-mecanicistas e as considerações de caráter histórico num único discurso, tornando possível aos homens pensarem a ordem jurídica histórica do ponto de vista de uma gênese ideal ou de uma concatenação de fatos hipotéticos, como na experiência de pensamento da história conjetural do "Discurso sobre a desigualdade". Cabe lembrar aqui que, quando Saussure (1967, p. 344) se refere ao sistema de signos como "convenção social" em seu "Cours de linguistique générale", a menção à obra do legislador busca apreender justamente o problema paradoxal da língua instituída por intermédio da própria língua: "Considera-se a língua como uma legislação à maneira dos filósofos do século XVIII". Contudo, se não quisermos conceder tanto peso ao aspecto retórico do legislador (mas correndo o risco de conceder demais à natureza), podemos ficar com a interpretação de Leo Strauss (1953, p. 288), para quem "a doutrina de Rousseau acerca do legislador pretende clarificar o problema fundamental da sociedade civil mais do que sugerir uma solução prática".

O "problema fundamental" na citação acima é o do nascimento das sociedades - o mesmo que Montesquieu enunciara em forma de paradoxo e que Rousseau traduz da seguinte maneira no "Contrato": “[...] seria necessário que o efeito pudesse tornar-se causa, que o espírito social - que deve ser a obra da instituição - presidisse à própria instituição, e que os homens fossem antes das leis o que deveriam tornar-se depois delas" (Rousseau, 1964, p. 383). Entretanto, o quadro teórico da análise de Strauss é fortemente marcado pela premissa metafísica de uma "teologia natural" (Strauss, 1953, pp. 276 e 293), o que leva a uma subordinação necessária da prática à teoria. Ora, sem 
pretensão de refutar neste artigo a interpretação de Strauss, noto apenas que, se a aceitássemos, seríamos simplesmente lançados de volta à questão inicial do artigo sobre a externalidade do legislador e do finalismo no cumprimento dos dogmas dos deuses. Assim, parece mais interessante contrastar essa leitura com uma outra de viés estruturalista, em que o direito natural não tem lugar, como no artigo "Sur le Contrat Social", de Louis Althusser (1967).

Althusser vê na formulação paradoxal da teoria contratual de Rousseau não o encaminhamento para a solução do problema descrito por Strauss, mas, de um ponto de vista estritamente lógico, o primeiro elemento de uma série de deslocamentos (décalages) argumentativos. De acordo com a estrutura do "Contrato social", nenhuma solução baseada em intervenção externa (não humana) seria possível: "Não haverá, portanto, solução transcendente, recurso a um terceiro, seja Deus, seja o acaso", explica Althusser (1967, p. 13). Ou seja, nem catástrofes, nem cataclismos, uma vez que, devido às condições impostas na formulação do problema teórico que é o "contrato social", os obstáculos não podem vir da natureza, mas antes, eles são necessariamente internos ao próprio problema e dizem respeito às relações humanas. Mais precisamente, o que ameaça a paz estabelecida pelo contrato social é, segundo Althusser, a concorrência recíproca alimentada pelo interesse particular. As próprias leis são objeto dessa concorrência na medida em que são ajustadas para legitimar relações de desigualdade entre os homens, de modo que a injustiça intrínseca à sociedade mesma só poderia ser evitada pelo recurso a uma instância legislativa acima de todos os homens, o que seria um absurdo metodológico no campo teórico rigorosamente estabelecido nos livros I e II. O legislador é esse ser de exceção que ocupa um não lugar na ordem jurídica do "Contrato": não tem "nenhuma relação com nossa natureza" e sua função "não tem nada em comum com o império humano" (Rousseau, 1964, pp. 381 e 382); todavia, sem o legislador a passagem para o estado civil legítimo não se efetiva, pois, por conhecer a fundo os corações humanos, somente ele é capaz de "transformar cada indivíduo, que por si mesmo é um todo perfeito e solitário, em parte de um todo maior" (Rousseau, 1964, p. 381). Em suma, para Althusser, Rousseau não resolve o problema, mas apenas desloca seus termos até que, no limite, Rousseau não tem outra saída a não ser a "fuga para a ideologia" (Althusser, 1967, p. 42). O comércio entre homens e deuses é impossível pelo simples fato de os deuses não passarem de um artifício retórico para comover homens vulgares e despertar neles a consciência da soberania na ordem civil. $\mathrm{Na}$ verdade, resta pouca coisa após a demolição lógica de Althusser, que, em complemento à recusa da realidade externa ao modelo, mostra ainda que nem mesmo o comércio interno entre os homens é possível, pelo menos do ponto 
de vista da realidade histórica, pois trata-se de um contrato entre duas partes interessadas (os indivíduos antes do pacto e a comunidade que o pacto institui) no qual a segunda parte é produto da primeira e, portanto, não preexiste ao contrato.

Entre os polos de nossa escala, o naturalismo de Strauss e o estruturalismo de Althusser, preferimos um meio-termo para compreender a natureza no modelo contratualista de Rousseau. Lembremos que, no "Contrato", o problema do ordenamento civil é formulado no interior do quadro conceitual dos cientistas do século XVII, ou seja, como uma experiência do pensamento. A ponderação fundamental envolve, além dos princípios do direito político, também ideias e imagens das investigações de moral e de educação, podendo ser assim enunciada: se, de direito, o corpo político é laico, mas, de fato, os homens são dependentes de deuses legisladores, então, convém conceber a sociedade possível como se os cidadãos fossem crianças que precisam de guias legalistas semelhantes aos deuses até atingirem a idade da autonomia. Isso posto, parece-nos razoável concluir que o recurso à religião no "Contrato", longe de representar um retorno à teologia natural (Strauss) ou uma fuga para a ideologia (Althusser), serve para expressar a raridade do sucesso da obra do legislador e, no modelo da escala do juízo, ${ }^{9}$ estabelecer o grau máximo de legitimidade para avaliação das sociedades historicamente instituídas. Novamente, é a dicotomia entre teoria e prática que estabelece as condições de possibilidade de uma associação legítima e segura. De um lado, é preciso enunciar o que deve ser aos homens, esclarecendo-os acerca da soberania e fazendo com que sejam, efetivamente, autores das leis que somente uma "inteligência superior" poderia conceber. De outro, os exemplos históricos alertam quanto ao perigo que nasce junto com a própria sociedade no ato da legiferação, ao mesmo tempo que caracterizam o milagre da extraordinária autoridade capaz de transformar a natureza humana, mas que, contudo, não ambiciona o poder legislativo que pertence exclusivamente ao povo. Em suma,

9 A ideia de escala do juízo aparece no "Emílio", livro V (Rousseau, 1969, p. 837). A metáfora é a da régua da justiça: no grau máximo de legitimidade, tem-se a representação dos interesses do povo totalmente coerentes com o interesse comum, o que corresponde à imagem de um corpo político movido pela vontade geral; é esse parâmetro extremo que servirá de medida de direito para se julgar a legitimidade de fato das associações historicamente instituídas, nas quais a alienação no ato do pacto nunca terá sido total (pois somente a alienação total é que constitui a legitimidade da autoridade soberana e distingue o mero agregado da verdadeira associação). Julgar os fatos pelo direito significa, nessa metáfora, encontrar uma regra de direito sob a qual todos os fatos possam ser subsumidos. Em termos práticos, não se trata de buscar em meio aos povos reais um caso particular no qual a vontade geral tenha de fato se instituído; o que está em questão diz respeito ao direito, ou seja, Rousseau busca mensurar o afastamento do caso empírico relativamente ao parâmetro extremo na escala do juízo. A melhor interpretação do "Contrato" como escala entre teoria e prática parece-me ser dada por Milton Meira do Nascimento (1988). 
Rousseau está menos interessado na possibilidade de um legislador histórico do que na dupla consideração, histórica e filosófica, do problema do contrato. Não custa notar que a célebre fórmula que atribui caráter divino ao legislador - "Seriam precisos deuses para dar leis aos homens" (Rousseau, 1964, p. 381) - é expressa com o verbo no condicional, o que nos lembra imediatamente da perspectiva de Rousseau acerca do problema: uma experiência do pensamento semelhante àquela do modelo de Grotius no "De jure belli ac pacis" (1625), ${ }^{10}$ uma vez que, no "Contrato", a obediência às santas leis seria efetiva mesmo que os deuses não existissem de fato. O legislador implanta a polícia interna no coração dos cidadãos - o amor à pátria reforçado pelos usos e costumes -, o que se mostra muito mais eficaz do que a força coercitiva exercida pelo governo, que controla apenas a aparência externa de virtude; o sucesso de sua missão está em fazer com que a moralidade se sobreponha à legalidade nos móbiles das ações dos indivíduos. Kant, na "Metafísica dos costumes" (1797), não deixará de concordar com essa formulação do modelo social.

Com base nas considerações aqui desenvolvidas, poderíamos concluir dizendo que os capítulos do legislador e da religião civil no "Contrato" não precisam ser vistos necessariamente como deslocamentos althusserianos; pois, levando-se em conta o duplo registro discursivo de Rousseau, é possível verificar que, longe de ser uma mera "fuga para a ideologia", a lógica paradoxal que estrutura o problema do contrato social é justamente a condição complexa que permite a Rousseau costurar sincronia e diacronia em seu discurso sobre a legislação, sendo a retórica do legislador e os dogmas da religião civil os elementos mobilizados para tal tarefa. O legislador e a religião civil se justificam como componentes necessários na economia interna do "Contrato" pela mesma razão por que os pontos de vista teórico e prático não podem ser compreendidos separadamente: uma visão estritamente jurídica poderia até ser compatível com o paradigma mecanicista, mas sabemos que os esquemas de inteligibilidade que Rousseau mobiliza para descrever o corpo político são os da criança que sai da menoridade rumo à condição autônoma guiada por um tutor e, por isso, pressupõem, em algum sentido, uma perspectiva finalista da sociedade; da mesma forma, uma visão estritamente historicista (obviamente, sem a ideia de providência) poderia ser insuficiente do ponto de vista filosófico, pois não apenas careceria de leis gerais que pudessem explicar as conexões

10 O conhecimento do homem é uma ciência da razão, pois é natural, em oposição ao conhecimento revelado das Escrituras, que é sobrenatural e que depende da fé religiosa. É no interior desse quadro teórico que Grotius, teorizando à luz da razão, afirma que sua ciência do direito seria válida mesmo que Deus não existisse (Grotius, 2004, Vol. I, § 11, pp. 40-41). 
necessárias na série de fatos concatenados, mas também correria o risco de ter que admitir a verdade factual dos dogmas da política a despeito da orientação geral dos princípios do direito; no fundo, o equívoco seria julgar o direito pelos fatos, como no pacto do rico descrito no "Discurso sobre a desigualdade". Somente a união desses dois registros discursivos permite a Rousseau pensar no corpo político tanto do ponto de vista de suas relações internas necessárias quanto em termos da imponderabilidade das relações humanas que nenhuma lei geral pode prever. É nesse procedimento de tessitura da escrita que o "Contrato social" adquire sua necessária coerência.

\section{Referências}

ALTHUSSER, L. "Sur le Contrat Social”. Les Cahiers pour l'Analyse, Paris, Nr. 8, 1967. BERNARDI, B. "La Fabrique des concepts: recherches sur l'invention conceptuelle chez Rousseau". Paris: Honoré Champion, 2006.

GOLDSCHMIDT, V. "Rousseau et le droit". In : .Écrits, t. II. Paris: J. Vrin, 1984. GOYARD-FABRE, S. "Filosofia crítica e razão jurídica". São Paulo: Martins Fontes, 2006.

GROTIUS, H. "O direito da guerra e da paz". Trad. C. Mioranza e A. M. Hespanha. Ijuí: Unijuí; FondazioneCassamarca, 2004. 2 Vol.

HOBBES, T. “Leviatã”. Trad. J. P. Monteiro e M. B. N. da Silva. São Paulo: Abril, 1974. KANT, I. "Metafísica dos costumes". Trad. C. A. Martins et al. Petrópolis: Vozes, 2013. KAWAUCHE, T. "Religião e política em Rousseau: o conceito de religião civil". São Paulo: Humanitas; FAPESP, 2013.

MAQUIAVEL, N. "Discursos sobre a primeira década de Tito Lívio". São Paulo: Martins Fontes, 2007.

MONTESQUIEU, C. L. de S., Baron de. "Considérations sur les causes de la grandeur des romains et de leur décadence”. In: Euvres complètes, t. II. Ed. Roger Caillois. Paris: Gallimard, 1951 (Col. Bibl. Pléiade).

. "O espírito das leis". Trad. C. Murachco. $2^{\mathrm{a}}$ ed. São Paulo: Martins Fontes, 1996.

NASCIMENTO, M. M. "O contrato social: entre a escala e o programa". Discurso (USP), Nr. 17, 1988.

QUANTIN, J.-L. "Le mythe du législateur au XVIII" siècle: état de recherches". In: GRELL, C., MICHEL, C. (orgs.). Primitivisme et mythes dans la France des Lumières (1680-1820). Paris: Presses Universitaires de la Sorbonne, 1989.

ROUSSEAU, J.-J. “Euvres complètes”. Ed. B. Gagnebin M. Raymond. Paris: Gallimard, 1964 (t. III); 1969 (t. IV) (Col. Bibliothèque de la Pléiade).

. "O contrato social: princípios do direito político". Trad. A. P. Danesi. $3^{\mathrm{a}}$ ed.

São Paulo: Martins Fontes, 1999.

SALINAS FORTES, L. R. "Rousseau: da teoria à prática". São Paulo: Ática, 1976.

SAUSSURE, F. "Cours de linguistique générale”. Paris: Payot, 1967. 
STAROBINSKI, J. “J.-J. Rousseau: la transparence et l'obstacle, suivi de Sept essais sur Rousseau". Paris: Gallimard, 1971.

. "Rousseau et l'éloquence". In: LEIGH, R. A. (Ed.). Rousseau after Two Hundred Years. Cambridge University Press, 1982.

STRAUSS, L. "Natural Right and History". University of Chicago Press, 1953. 